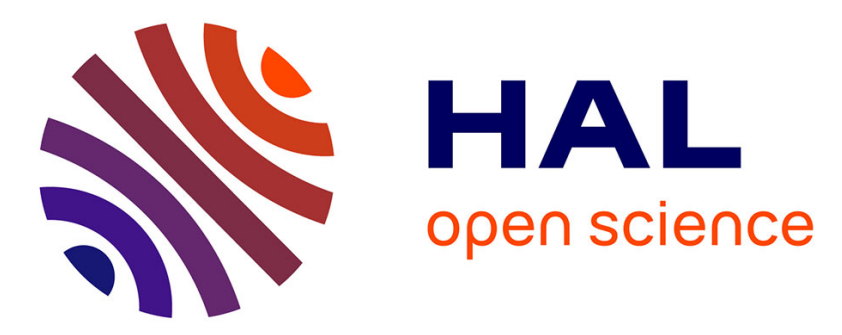

\title{
First record of the invasive land flatworm Bipalium adventitium (Platyhelminthes, Geoplanidae) in Canada
}

Jean-Lou Justine, Thomas Thery, Delphine Gey, Leigh Winsor

\section{To cite this version:}

Jean-Lou Justine, Thomas Thery, Delphine Gey, Leigh Winsor. First record of the invasive land flatworm Bipalium adventitium (Platyhelminthes, Geoplanidae) in Canada. Zootaxa, 2019, 4656 (3), pp.591-595. 10.11646/zootaxa.4656.3.13 . hal-02283165

\section{HAL Id: hal-02283165 \\ https://hal.sorbonne-universite.fr/hal-02283165}

Submitted on 10 Sep 2019

HAL is a multi-disciplinary open access archive for the deposit and dissemination of scientific research documents, whether they are published or not. The documents may come from teaching and research institutions in France or abroad, or from public or private research centers.
L'archive ouverte pluridisciplinaire HAL, est destinée au dépôt et à la diffusion de documents scientifiques de niveau recherche, publiés ou non, émanant des établissements d'enseignement et de recherche français ou étrangers, des laboratoires publics ou privés. 


\title{
Article
}

\section{First record of the invasive land flatworm Bipalium adventitium (Platyhelminthes, Geoplanidae) in Canada}

\author{
JEAN-LOU JUSTINE ${ }^{15}$, THOMAS THÉRY ${ }^{2}$, DELPHINE GEY ${ }^{3}$ \& LEIGH WINSOR ${ }^{4}$ \\ ${ }^{\prime}$ Institut Systématique Évolution Biodiversité (ISYEB), Muséum National d'Histoire Naturelle, CNRS, Sorbonne Université, EPHE, \\ Université des Antilles, 57 rue Cuvier, CP 51, 75005 Paris, France \\ ${ }^{2}$ Institut de Recherche en Biologie Végétale (IRBV), Centre sur la Biodiversité, 4101 rue Sherbrooke Est, H1X2B2 Montréal, Québec, \\ Canada \\ ${ }^{3}$ Service de Systématique Moléculaire, UMS 2700, Muséum National d'Histoire Naturelle, 57 rue Cuvier, CP 26, 75005 Paris, \\ France \\ ${ }^{4}$ College of Science and Engineering, James Cook University, Townsville, Australia \\ ${ }^{5}$ Corresponding author. E-mail: justine@mnhn.fr
}

\section{Summary}

Specimens of Bipalium adventitium (Platyhelminthes, Geoplanidae) were found in Montréal, Québec, Canada. The specimens showed the typical colour pattern of the species and barcoding (Cytochrome Oxidase I) demonstrated nearidentity with a sequence of the same species from the USA. This is the first record of the species in Canada.

Résumé. Des spécimens de Bipalium adventitium (Plathelminthes, Geoplanidae) ont été trouvés à Montréal, Québec, Canada. Les spécimens montraient le motif de couleur typique de l'espèce et le barcode (cytochrome oxydase I) était quasi-identique à une séquence de la même espèce provenant des États-Unis. Ceci est la première mention de l'espèce au Canada.

Land flatworms are transported with earth and pot plants between continents and often become invasive (Justine $e t$ al., 2014, 2015; Winsor, 1983) Since land flatworms are predators, they constitute a potential danger for the local soil fauna of the areas they invade. Among these land flatworms (family Geoplanidae), the hammerhead flatworms (subfamily Bipaliinae) are spectacular, by their large size, up to one meter, their distinctive colours, and the typical shape of their head which makes them easy to identify (Winsor, 1983). Most species have their origin in Asia but have invaded the world. The two "giant" species Bipalium kewense Moseley, 1878 and Diversibipalium multilineatum (Makino \& Shirasawa, 1983), which can be as long as $30 \mathrm{~cm}$, have been reported in many locations worldwide (Justine et al., 2018b; Mazza et al., 2016; Morffe et al., 2016; Winsor, 1983). Bipalium adventitium Hyman, 1943, which is smaller, but still a noticeable species up to about $10 \mathrm{~cm}$ in length, is known only from the USA (Hyman, 1943; Kawakatsu et al., 2002); however, since bipaliines do not have their biogeographical origin in North America, the species is not a part of the native fauna. Rather it is an invasive species known only from its invaded land.

In this paper, we record a finding of Bipalium adventitium in Montréal, Canada, with identification based on both external morphological and molecular characters.

Specimens were collected by one of us (TT). One specimen, 13 May 2018, Mont Royal, Montréal, Québec, Canada, $\mathrm{N} 45.5074^{\circ}, \mathrm{W} 73.6091^{\circ}$, under a stone in a land covered with trees (mainly sugar maple, Acer saccharum Marsh., northern red oak, Quercus rubra L., and American basswood, Tilia americana L.) ; specimen photographed then lost by the post. One specimen, 27 May 2018, under a stone, Montréal, N 45.5069 $\mathrm{W} 73.6111^{\circ}$, deposited in Muséum National d'Histoire Naturelle, Paris, France (MNHN) as MNHN JL327, sampled for molecular analysis. One specimen, 27 May 2018, under a stone, Montréal, N 45.5069 ${ }^{\circ}$ W $73.6087^{\circ}$, deposited in MNHN as MNHN JL328, sampled for molecular analysis. Two specimens, 30 September 2018, Montréal, N 45.5069 , W 73.6111 , under a stone (in the Collection Entomologique Ouellet-Robert, University of Montréal, Canada (QMOR) and in T. Théry Collection, France). Four specimens, 11 May 2019, Montréal, including two under a stone, N 45.5069 , W 
$73.6110^{\circ}$ and $\mathrm{N} 45.5074^{\circ}$, W $73.6083^{\circ}$ (in the Canadian National Collection of Insects, Arachnids and Nematodes, Ottawa, Canada (CNC), and two under a rotten $\log , \mathrm{N} 45.5072^{\circ}, \mathrm{W} 73.6083^{\circ}$ (in the Collection of the Insectarium of Montréal, Canada (IMQC), and in T. Théry Collection, France). Specimens were collected alive and photographed. They were then fixed in pure ethanol and a small portion of the specimen was taken for molecular analysis. Sequences were obtained using our routine protocol (Justine et al., 2018b). Briefly, genomic DNA was extracted using the QIAamp DNA Mini Kit (Qiagen). Fragments of the COI gene were amplified with the primers BarS , COIR, JB3 and JB4.5. PCR products were purified and sequenced in both directions on a 3730xl DNA Analyzer 96-capillary sequencer (Applied Biosystems). Results of both analyses were concatenated to obtain a COI sequence of 401 bp in length. The sequence was edited using CodonCode Aligner software (CodonCode Corporation, Dedham, MA, USA), compared to the GenBank database content using BLAST and deposited in GenBank under accession number MN192402 and MN192403. MEGA7 (Kumar et al., 2016) was used to estimate genetic distances. A phylogenetic analysis was performed with our new sequence and from all sequences available for members of the Bipaliinae; the geographical origin of specimens was checked in publications pertaining to sequences (Álvarez-Presas et al., 2008; Justine et al., 2018b; Moon et al., 2011) For the ML tree, the best model determined by MEGA7 was the Hasegawa-Kishino-Yano model with discrete Gamma distribution $(\mathrm{HKY}+\mathrm{G})$.

The specimens, about $60 \mathrm{~mm}$ in length when alive (Fig 1a), are elongate with the expanded headplate typical of bipaliines, tapering to a pointed posterior end. The dorsal ground colour was yellow-brown ("Raw Sienna") with a fine dark brown median dorsal stripe that does not extend onto the head. The headplate is fan-shaped without recurved lappets, and greyish around the anterior margin (Fig 1b). The ventral surface is a pale cream colour. The eye pattern and the presence of a gonopore were not examined. The external morphology of the specimens accords well with the original description of the species (Hyman, 1943).

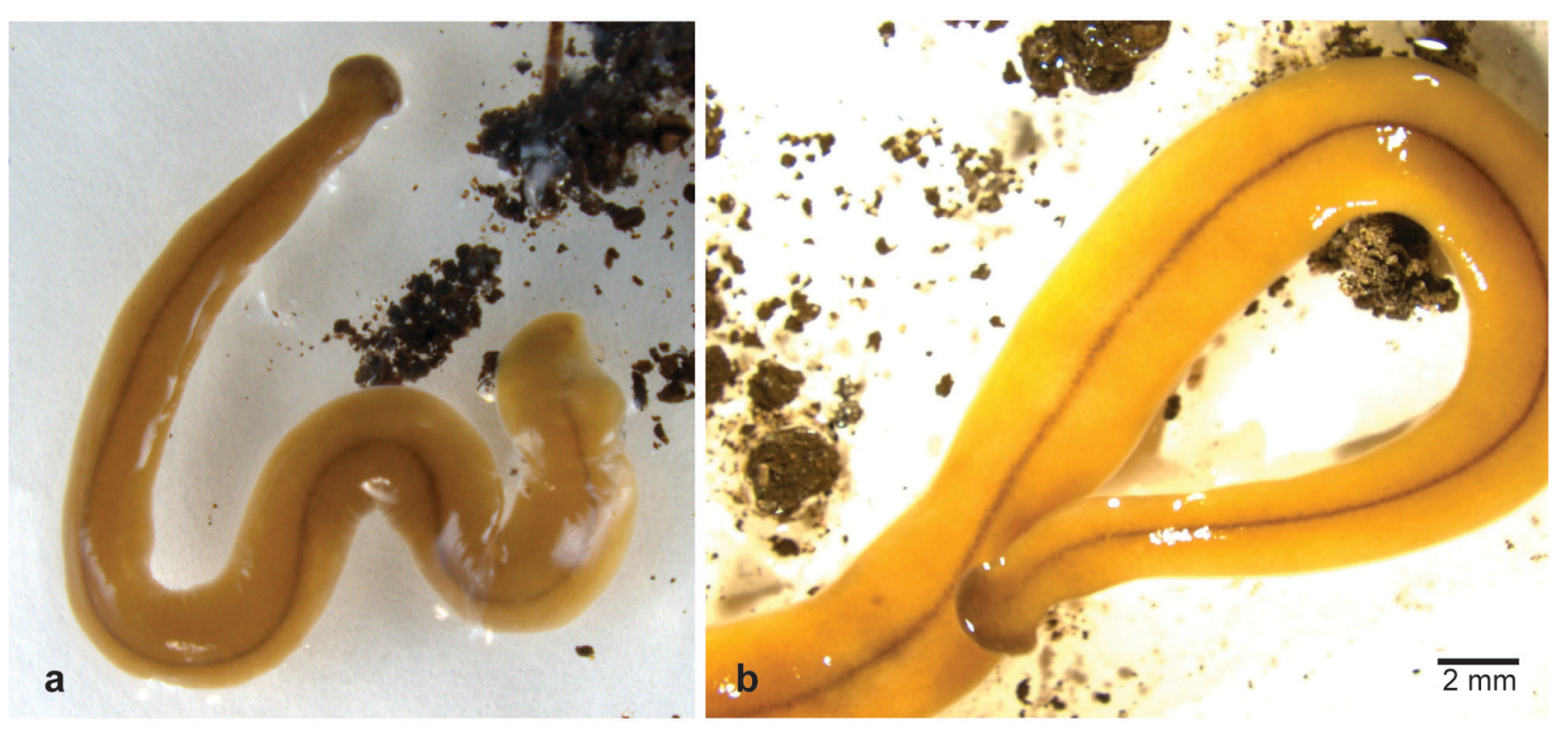

FIGURE 1. Living specimens. from Montréal, Québec. a. Bipalium adventitium, whole specimen, dorsal aspect. Figure 1 b. Bipalium adventitium, anterior end, dorsal aspect. Note the fan-shaped headplate with darker anterior margin, and the dark median dorsal stripe that terminates before the headplate.

The two specimens JL327 and JL328 had identical COI sequences. A tree was built from all sequences available for members of the Bipaliinae; for Bipalium kewense, Bipalium vagum and Diversibipalium multilineatum, since the sequences from various localities are identical (Justine et al., 2018b), only one sequence was used. The Maximum Likelihood tree is shown in Figure 2. The two sequences of Bipalium adventitium from Montréal, Canada formed a monophylum with $B$. adventitium from Kingston, Pennsylvania, USA; indeed, for the part of the COI sequence included in the matrix, the three sequences are identical. The tree provides a clear indication that the species found in Montréal and Kingston is the same; however, the very low value of most branches precludes any attempts as using the tree to understand phylogenetic relationships between species. The distance ( $\mathrm{p}$-distance) from B. adventitium to the other bipaliine species in the analysis ranged from $12.6 \%$ (B. kewense) to $18.2 \%$ (Diversibipalium sp. "blue" from Mayotte). We noted that two sequences had aberrant positions in the tree: HM346597, allegedly B. adventitium 
and HM346600, allegedly D. multilineatum; these sequences formed a clade with no relation with either of the two species mentioned. This may indicate that the original specimens were misidentified.

The morphological characters, colour pattern and the similarity of COI sequence clearly indicate that the specimens found in Montréal, Québec, are B. adventitium. Bipalium adventitium is a predator of earthworms (Ducey \& Noce, 1998; Zaborski, 2002) The species actively tracks its prey, follows trails of earthworm mucus and can capture earthworms in their tunnels (Fiore et al., 2004). It can prey on earthworms 55 times larger than itself in mass (Zaborski, 2002). The species reproduces by sexual reproduction, laying egg capsules that take about 23 days to hatch and contain 1-8 offspring (Ducey et al., 2005). As it often occurs with other invasive species, it has no known predator and experiments with salamanders and snakes have demonstrated that potential native predators do not consume it (Ducey et al., 1999). Bipalium adventitium is one of the two species of terrestrial animals, with B. kewense, in which the presence of tetrodotoxin, a powerful neurotoxin, has been identified (Stokes et al., 2014). An analysis of interactions of invasive and native plants and animals identified Bipalium adventitium as one of the many species involved in complex relationships of what the authors named an "extensive invasional meltdown in North America" (Heimpel et al., 2010).

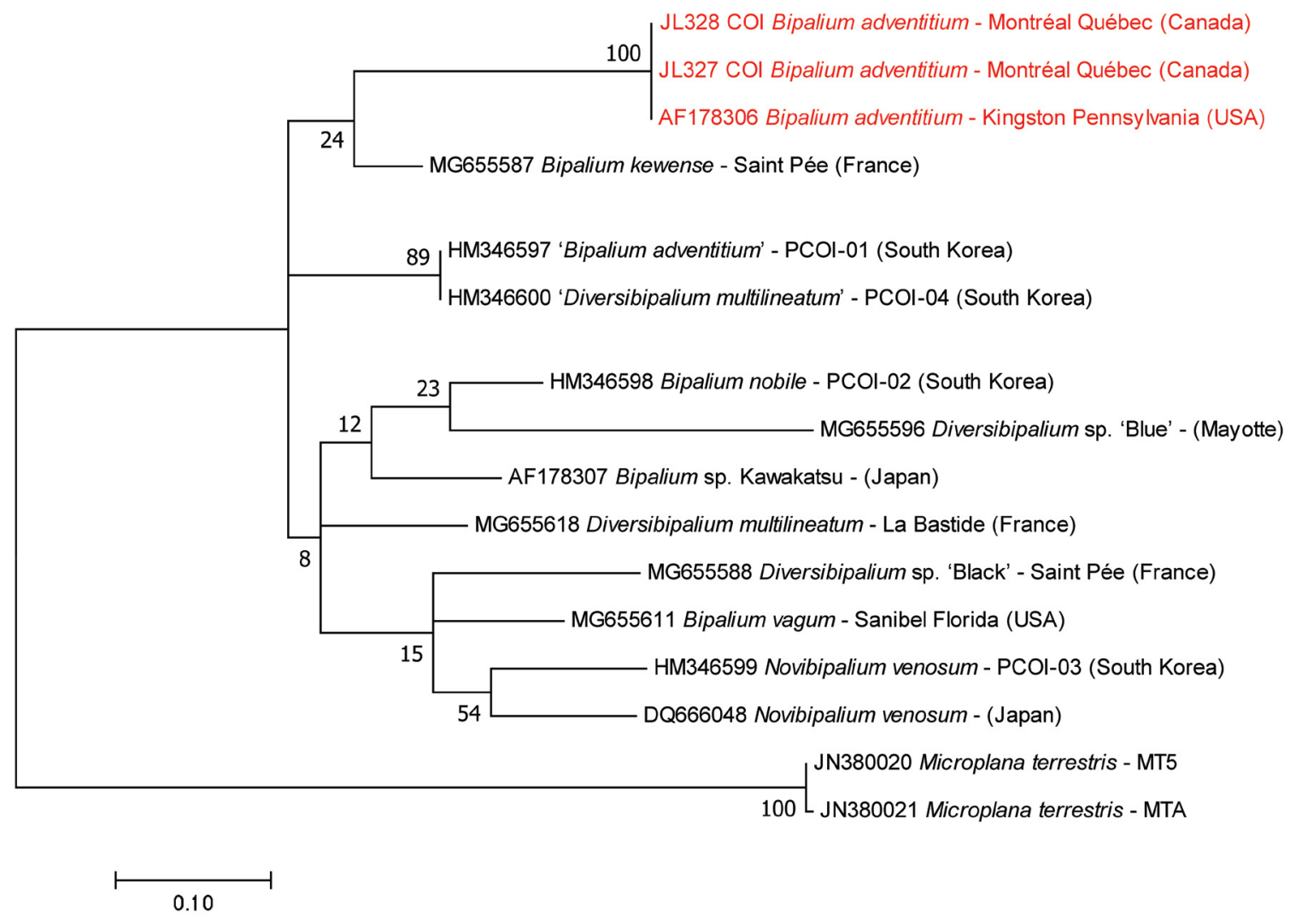

FIGURE 2. Maximum-likelihood tree of bipaliines, based on COI sequences. Localities are indicated for specimens. For sequence AF178306, the actual locality is Kingston, Pennsylvania, USA (erroneously indicated as "Leingston, USA") in the paper (Marta Álvarez-Presas, personal communication, 18 April 2019). Red: Bipalium adventitium.

After its description based on specimens from California (Hyman, 1943), the species has been recorded from a number of US states, including California, Illinois, Massachusetts, Michigan, Ohio, New York, Pennsylvania, Tennessee and West Virginia (Álvarez-Presas et al., 2008; Ducey \& Noce, 1998; Ducey et al., 2005; Fiore et al., 2004; Kawakatsu et al., 2002; Stokes et al., 2014; Zaborski, 2002). A search in GBIF ( https://www.gbif.org/species/5892130) yielded about 80 occurrences (April 2019), mostly from citizen science, in various states, mainly along the Eastern and Western coasts of the USA. The finding in Montréal is probably the Northernmost record of B. adventitium in North America, and our observations over two years show that the species can survive winter in Québec. Bipalium adventitium is a potential threat to the soil fauna and the presence of invasive land flatworms in an additional country should be recorded, especially with molecular information (Breugelmans et al., 2012; Chaisiri et al., 2018; Justine et al., 2018a; Mazza et al., 2016; Morffe et al., 2016). 
The COI sequences of bipaliine species differed by more than $10 \%$, suggesting that COI barcode can be reliably used for the identification of species of bipaliines. Longer sequences, such as complete mitogenomes, will be useful in the future (Gastineau et al., 2019) In our analysis, we remarked that two COI sequences did not group with the species corresponding to the names entered in GenBank when the sequences were deposited; these are HM346597, allegedly $B$. adventitium and HM346600, allegedly D. multilineatum, both from South Korea and both from the same paper (Moon et al., 2011). These sequences should not be used for future identification of bipaliine species.

\section{Acknowledgements}

Marta Álvarez-Presas kindly corrected a misspelling in the Table of her 2008 paper, about the locality of the specimens from the USA. The photographs were taken in Colin Favret's laboratory (Université de Montréal).

\section{References}

Álvarez-Presas, M., Baguñà, J. \& Riutort, M. (2008) Molecular phylogeny of land and freshwater planarians (Tricladida, Platyhelminthes): from freshwater to land and back. Molecular Phylogenetics and Evolution, 47, 555-568. https://doi.org/10.1016/j.ympev.2008.01.032

Breugelmans, K., Quintana Cardona, J., Artois, T., Jordaens, K. \& Backeljau, T. (2012) First report of the exotic blue land planarian, Caenoplana coerulea (Platyhelminthes, Geoplanidae), on Menorca (Balearic Islands, Spain). Zookeys, 199, 91-105. https://doi.org/10.3897/zookeys.199.3215

Chaisiri, K., Dusitsittipon, S., Panitvong, N., Ketboonlue, T., Nuamtanong, S., Thaenkham, U., Morand, S. \& Dekumyoy, P. (2018) Distribution of the newly invasive New Guinea flatworm Platydemus manokwari (Platyhelminthes: Geoplanidae) in Thailand and its potential role as a paratenic host carrying Angiostrongylus malaysiensis larvae. Journal of Helminthology, 1-9. [online] https://doi.org/10.1017/S0022149X18000834

Ducey, P.K., Messere, M., Lapoint, K. \& Noce, S. (1999) Lumbricid prey and potential herpetofaunal predators of the invading terrestrial flatworm Bipalium adventitium (Turbellaria: Tricladida: Terricola). American Midland Naturalist, 141, $305-314$. https://doi.org/10.1674/0003-0031(1999)141[0305:LPAPHP]2.0.CO;2

Ducey, P.K. \& Noce, S. (1998) Successful invasion of New York State by the terrestrial flatworm, Bipalium adventitium. Northeastern Naturalist, 5, 199-206. https://doi.org/10.2307/3858619

Ducey, P.K., West, L.-J., Shaw, G. \& De Lisle, J. (2005) Reproductive ecology and evolution in the invasive terrestrial planarian Bipalium adventitium across North America. Pedobiologia, 49, 367-377. https://doi.org/10.1016/j.pedobi.2005.04.002

Fiore, C., Tull, J.L., Zehner, S. \& Ducey, P.K. (2004) Tracking and predation on earthworms by the invasive terrestrial planarian Bipalium adventitium (Tricladida, Platyhelminthes). Behavioural Processes, 67, 327-334. https://doi.org/10.1016/S0376-6357(04)00138-X

Gastineau, R., Justine, J.-L., Lemieux, C., Turmel, M. \& Witkowski, A. (2019) Complete mitogenome of the giant invasive hammerhead flatworm Bipalium kewense. Mitochondrial DNA, Part B, 4, 1343-1344. https://doi.org/10.1080/23802359.2019.1596768

Heimpel, G.E., Frelich, L.E., Landis, D.A., Hopper, K.R., Hoelmer, K.A., Sezen, Z., Asplen, M.K. \& Wu, K. (2010) European buckthorn and Asian soybean aphid as components of an extensive invasional meltdown in North America. Biological Invasions, 12, 2913-2931. https://doi.org/10.1007/s10530-010-9736-5

Hyman, L.H. (1943) Endemic and exotic land planarians in the United States: with a discussion of necessary changes of names in the Rhynchodemidae. American Museum Novitates, 1-21.

Justine, J.-L., Lemarcis, T., Gerlach, J. \& Winsor, L. (2018a) First report of the land planarian Endeavouria septemlineata (Hyman, 1939) (Platyhelminthes, Tricladida, Continenticola, Geoplanidae) in French Polynesia. Zootaxa, 4450, $297-300$. https://doi.org/10.11646/zootaxa.4450.2.10

Justine, J.-L., Winsor, L., Barrière, P., Fanai, C., Gey, D., Han, A.W.K., Quay-Velazquez, G. L.a., Lee, B.P.Y-H., Lefevre, J.-M., Meyer, J.-Y., Philippart, D., Robinson, D.G., Thevenot, J. \& Tsatsia, F. (2015) The invasive land planarian Platydemus manokwari (Platyhelminthes, Geoplanidae): records from six new localities, including the first in the USA. PeerJ, 3 , e1037. https://doi.org/10.7717/peerj.1037

Justine, J.-L., Winsor, L., Gey, D., Gros, P. \& Thévenot, J. (2014) The invasive New Guinea flatworm Platydemus manokwari in France, the first record for Europe: time for action is now. PeerJ, 2, e297. 
https://doi.org/10.7717/peerj.297

Justine, J.-L., Winsor, L., Gey, D., Gros, P. \& Thévenot, J. (2018b) Giant worms chez moi! Hammerhead flatworms (Platyhelminthes, Geoplanidae, Bipalium spp., Diversibipalium spp.) in metropolitan France and overseas French territories. PeerJ, 6, e4672. https://doi.org/10.7717/peerj.4672

Kawakatsu, M., Ogren, R.E., Froehlich, E.M. \& Sasaki, G.-Y. (2002) Additions and corrections of the previous land planarian indices of the world (Turbellaria, Seriata, Tricladida, Terricola). Bulletin of the Fuji Women's College (Series 2), 40, $157-177$.

Kumar, S., Stecher, G. \& Tamura, K. (2016) MEGA7: Molecular Evolutionary Genetics Analysis version 7.0 for bigger datasets. Molecular Biology and Evolution, 33, 1870-1874. https://doi.org/10.1093/molbev/msw054

Mazza, G., Menchetti, M., Sluys, R., Solà, E., Riutort, M., Tricarico, E., Justine, J.-L., Cavigioli, L. \& Mori, E. (2016) First report of the land planarian Diversibipalium multilineatum (Makino \& Shirasawa, 1983) (Platyhelminthes, Tricladida, Continenticola) in Europe. Zootaxa, 4067 (5), 577-580. https://doi.org/10.11646/zootaxa.4067.5.4

Moon, D.-H., Lee, Y.A. \& Huh, M.K. (2011) Identification and phylogenetic relationship at Cytochrome Oxidase Subunit I (COI) gene among Korean terrestrial planarian taxa. Journal of Life Science, 21, 939-946. https://doi.org/10.5352/JLS.2011.21.7.939

Morffe, J., García, N., Adams, B.J. \& Hasegawa, K. (2016) First record of the land planarian Bipalium kewense Moseley, 1878 (Tricladida: Geoplanidae: Bipaliinae) from Cuba. BioInvasions Records, 5, 127-132. https://doi.org/10.3391/bir.2016.5.3.01

Stokes, A.N., Ducey, P.K., Neuman-Lee, L., Hanifin, C.T., French, S.S., Pfrender, M.E., Brodie, E. D., III \& Brodie Jr, E.D. (2014) Confirmation and distribution of Tetrodotoxin for the first time in terrestrial invertebrates: Two terrestrial flatworm species (Bipalium adventitium and Bipalium kewense). PLOS ONE, 9, e100718. https://doi.org/10.1371/journal.pone.0100718

Winsor, L. (1983) A revision of the Cosmopolitan land planarian Bipalium kewense Moseley, 1878 (Turbellaria: Tricladida: Terricola). Zoological Journal of the Linnean Society, 79, 61-100. https://doi.org/10.1111/j.1096-3642.1983.tb01161.x

Zaborski, E.R. (2002) Observations on feeding behavior by the terrestrial flatworm Bipalium adventitium (Platyhelminthes: Tricladida: Terricola) from Illinois. American Midland Naturalist, 148, 401-408. https://doi.org/10.1674/0003-0031(2002)148[0401:OOFBBT]2.0.CO;2 